\title{
Safety Evaluation of Fungal Pigments for Food Applications
}

\author{
Rajendran Poorniammal ${ }^{1, *}$, Somasundaram Prabhu ${ }^{2}$, Laurent Dufossé ${ }^{3, *} \mathbb{C}$ and Jegatheesh Kannan ${ }^{1}$ \\ 1 Department of Natural Resource Management, Horticultural College and Research Institute, \\ Tamil Nadu Agricultural University (TNAU), Periyakulam 625 604, India; kannan.j@tnau.ac.in \\ 2 Department of Plant Protection, Horticultural College and Research Institute, \\ Tamil Nadu Agricultural University (TNAU), Periyakulam 625 604, India; prabhu.s@tnau.ac.in \\ 3 Laboratoire de Chimie et Biotechnologie des Produits Naturels (CHEMBIOPRO), Université de La Réunion, \\ ESIROI Agroalimentaire, 15 Avenue René Cassin, F-97400 Sainte-Clotilde, France \\ * Correspondence: r.poornii@tnau.ac.in (R.P.); laurent.dufosse@univ-reunion.fr (L.D.); \\ Tel.: +33-668-73-19-06 (L.D.)
}

Citation: Poorniammal, R.; Prabhu,

S.; Dufossé, L.; Kannan, J. Safety Evaluation of Fungal Pigments for Food Applications. J. Fungi 2021, 7, 692. https://doi.org/10.3390/ jof7090692

Academic Editor: David S. Perlin

Received: 16 June 2021

Accepted: 23 August 2021

Published: 26 August 2021

Publisher's Note: MDPI stays neutral with regard to jurisdictional claims in published maps and institutional affiliations.

Copyright: (c) 2021 by the authors. Licensee MDPI, Basel, Switzerland. This article is an open access article distributed under the terms and conditions of the Creative Commons Attribution (CC BY) license (https:// creativecommons.org/licenses/by/ $4.0 /)$.

\begin{abstract}
Pigments play a major role in many industries. Natural colors are usually much safer when compared to synthetic colors and may even possess some medicinal benefits. Synthetic colors are economical and can easily be produced compared to natural colors. In addition, raw plant materials for natural colors are limited and season dependent. Microorganisms provide an alternative source for natural colors and, among them, fungi provide a wide range of natural colorants that could easily be produced cheaply and with high yield. Along with pigment, some microbial strains are also capable of producing a number of mycotoxins. The commercial use of microbial pigments relies on the safety of colorants. This review provides a toxicity evaluation of pigments from fungal origins for food application.
\end{abstract}

Keywords: fungal pigments; mycotoxins; safety evaluation; pigment toxicity

\section{Introduction}

Due to the global increase in processed food production, the market for fresh food is predicted to grow more in coming years. Modern consumers have become more nutrition and health conscious and have a growing interest in (i) where their food comes from and (ii) in food additives [1]. Food labeling has increased interest in understanding the physiological needs of the body. Consumers tend to shy away from chemical compounds such as food additives, viz., antioxidants, preservatives and colors. They search for natural additives in natural foods that are safe and good for them. On the other hand, consumers have a growing awareness of natural products where toxicants may also be present [2].

Historically, throughout the world, natural pigments have been used for many purposes. The advent of synthetic dyes reduced the use of natural pigments to a greater extent. Recently, dyes derived from natural sources are gaining importance, since some synthetic dyes have been reported to have carcinogenic effects [3,4]. Natural pigments gained interest due to worldwide concern over the use of eco-friendly and biodegradable materials. Demand for natural colorants, especially yellow and red pigments, israpidly increasing worldwide. Production of safe and natural pigments from natural resources are mainly being focused on in food, textile and pharmaceutical industries, due to the serious environmental and safety problems caused by many artificial synthetic pigments [5].

Many natural pigments are from plant or microorganism-based origins. There are a number of major drawbacks to plant pigments, viz., non-availability throughout the year, pigment stability and solubility. Exploitation of plants on a large scale may lead to a loss of valuable species. For these reasons, the pigments from plant sources are not considered viable. Microorganisms, viz., fungi, bacteria, algae and actinomycetes, are a reliable and readily available alternative source of natural pigments [6,7]. Microorganisms are advanta- 
geous over plant for pigments production because of easy and rapid multiplication in a low cost medium, easy processing and growth independent from weather conditions [8].

\section{Synthetic Food Colors}

Color is an important factor as far as food is concerned, as it plays a major role in the taste and perception of food, along with flavor and texture. It is a known fact that consumers will probably reject food that does not look attractive. To make food more appealing to customers, manufacturers add color to retain the food's natural look, as far as possible. Natural appearance is always preferable to anything that looks unusually colored. Even though many foods can contain added artificial colors, most consumers believe that the color of the food is its natural color.

The first synthetic organic dye, discovered by William Henry Perkin in 1856, was a purplish lilac color named "mauve". Similar organic aniline dyes were synthesized, representing every color and tint of the rainbow, and these were used for food coloring with little or few tests regarding their safety. Aniline and coaltar-based colors exhibited significant toxicity, which prompted regulators to examine the exact use of synthetic colors in the food industry [9].

In recent years, an astonishing amount of the food we eat is processed. To increase the shelf life and appearance of food, additives and colors are added, which make them unsafe for consumption. On average, processed food accounts for about $70 \%$ of the diet of U.S. residents. This includes soft drinks, confectionery, packaged bread, buns, biscuits, cakes, preserved meat products, instant soups, noodles, packaged pizzas, pies and packaged meals. The U.S. consumption of processed food is about forty times more than the diet of Indian residents [10].

\section{Health Hazards of Synthetic Food Colors}

Risk analysis helps to evaluate the adverse effects of synthetic agents in food. In a global context, food colors are of major concern with regard to the possible adverse effects of additives. In the mid-1980s, a possible link between tartrazine and hyperactivity in children was suggested [11].

1. The azo-dye group of colorants consists of bright colors and is widely used in the food industry. Increasing attention on these dyes revealed that they were potential carcinogens, occurring in the intestines' microbiota, after their azo reduction to carcinogenic metabolites [12]. Even at low levels of ingestion, permitted food colors, viz., ponceau, tartrazine and sunset yellow, provoked allergic reactions in many individuals. Common allergic responses were urticaria, dermatitis, angioedema and the exacerbation of asthmatic symptoms [13]. A symptom of glossitis was reported due to the consumption of a very high level of ponceau $4 \mathrm{R}$ in a particular brand of aniseed [14]. Hypertensive children aged between 2 and 14 years were diagnosed with irritability, restlessness and sleep disturbance due to high levels of tartrazine. Ever rising demand for the use of natural colorants has replaced the use of synthetic dyes in food [15].

\section{Microbial Pigments}

Natural pigments obtained from plants, animals and microorganisms are eco-friendly and have usually low or no toxicity [16,17]. The many disadvantages of using plants and animals prevent them from large-scale exploitation [18]. However, advantages of microbial pigments help to utilize their immense potential in various fields $[19,20]$. Even though the cost of microbial $\beta$-carotene production is several times more expensive, it can still compete with synthetic dyes in terms of it being natural and safe [21,22].

Microbial cells that produce color are referred to as microbial pigments producers [23]. They produce a wide range of colors (Figure 1) and are mostly water-soluble [24,25]. Natural pigments are mainly used as color additives or intensifiers; moreover, they are used as antioxidants and antibiotics (Figure 2). Due to indiscriminate use of synthetic colors and contrary reports on the safety of synthetic dyes, there is an important need to identify 
safe colorants from natural pigments. Microbial pigments have several advantages, viz., yield, cost efficiency, stability and ease of downstream processing compared to pigments from plant or animal origins [26,27].

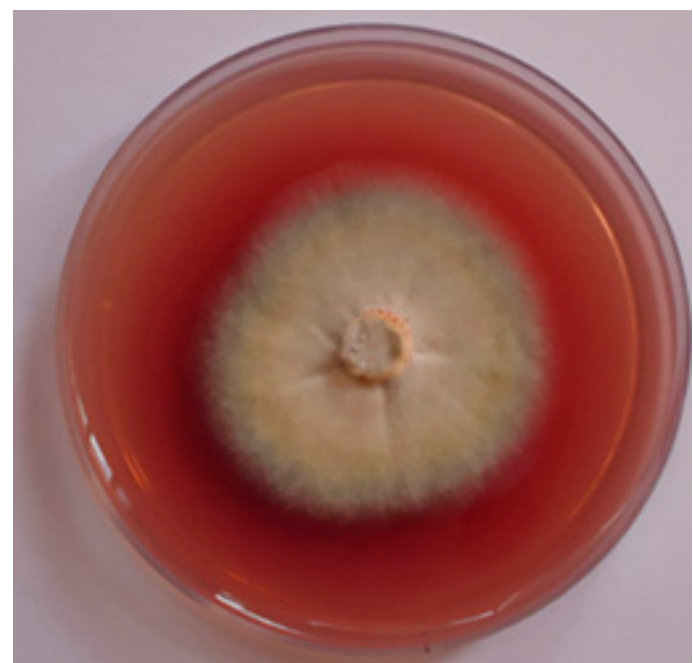

(a)

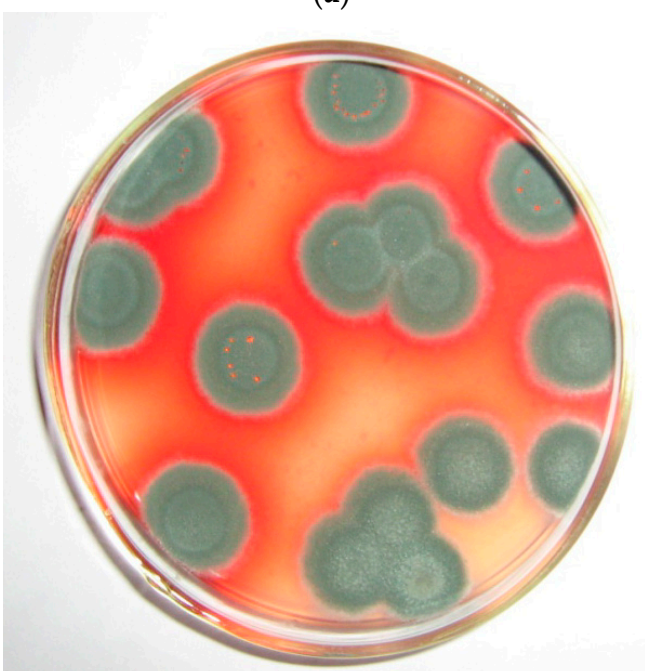

(c)

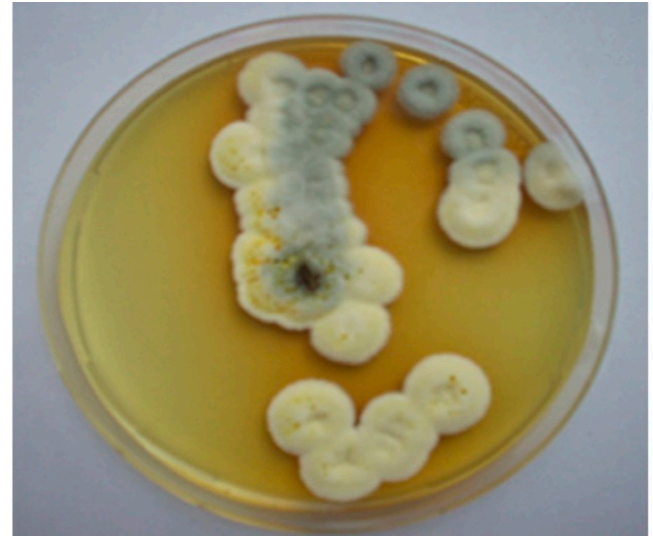

(e)

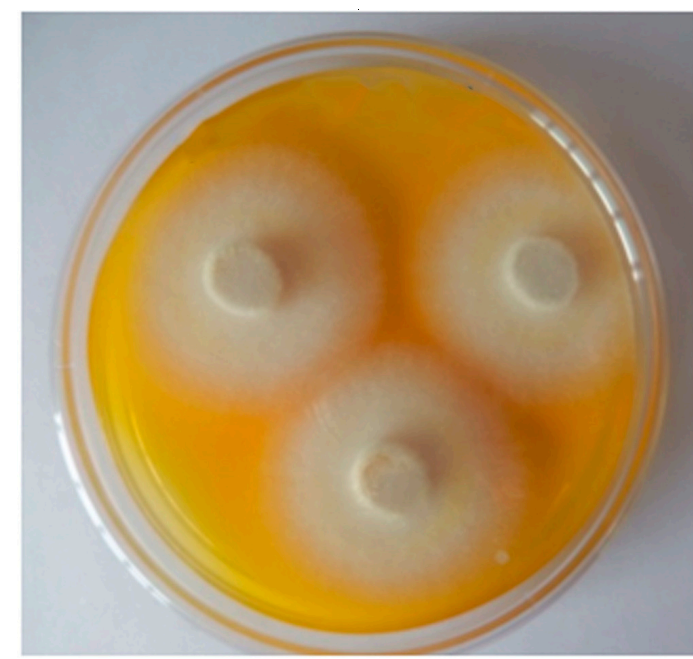

(b)

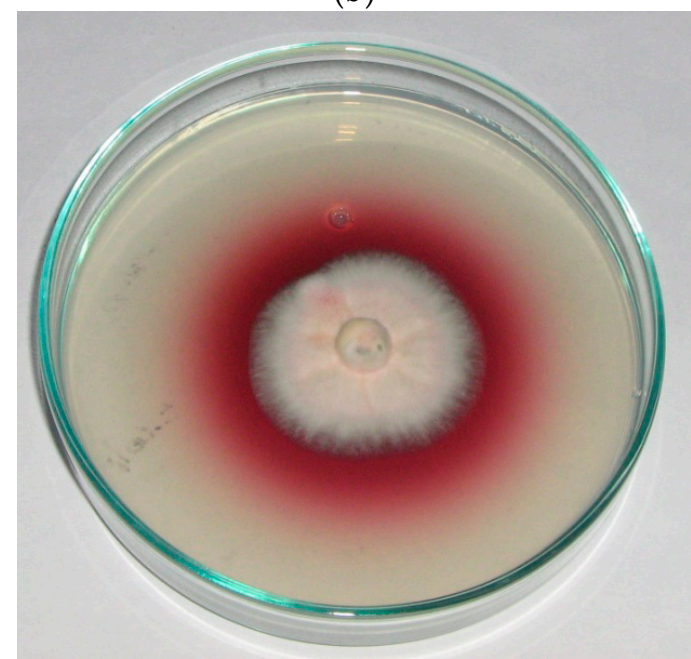

(d)

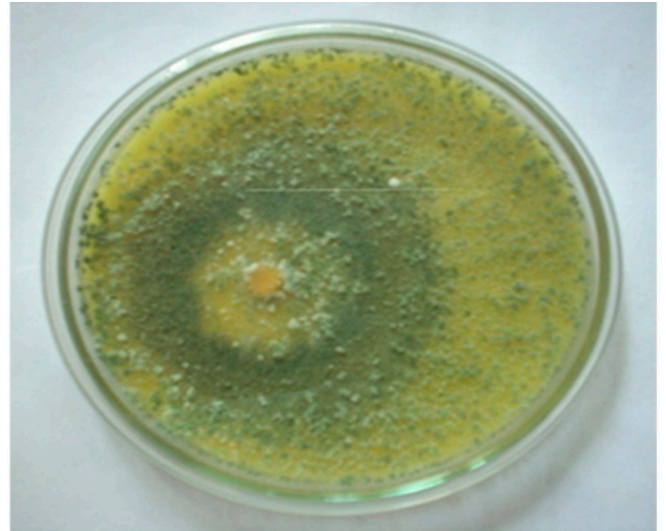

$(\mathbf{f})$

Figure 1. Pigments produced by different fungi: (a) Chaetomium sp. producing red pigment; (b) Thermomyces sp. producing yellow pigment; (c) Penicillium purpurogenum producing red pigment; (d) Fusarium sp. producing red pigment; (e) Penicillium purpurescens producing brown pigment (f) Trichoderma sp. producing yellow pigment. 


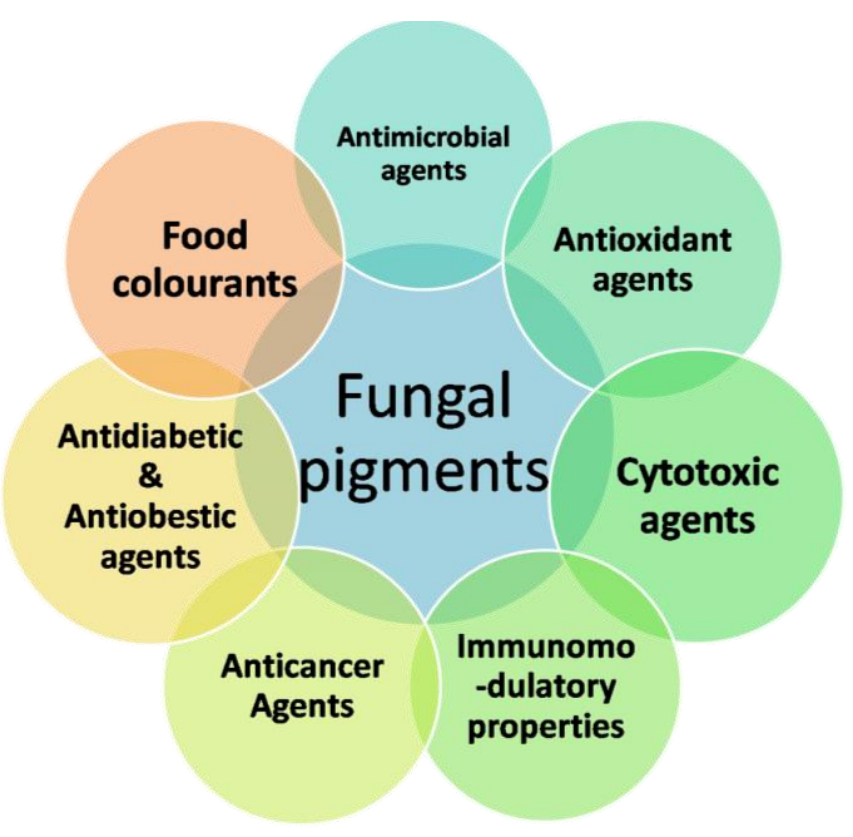

Figure 2. Applications of fungal pigments in the food industry.

Among pigment-producing microbes, fungi produce a wide range of water-soluble biopigments that have a variety of functions. Pigments extracted from fungi that are isolated from soil have various industrial applications. Filamentous fungi, viz., Monascus, Aspergillus, Penicillium, Neurospora, Eurotium, Drechslera and Trichoderma [28-30] are potential producers of bio-pigments. The pigments include carotenoids, melanins, flavins, phenazines, quinones, monacins and indigo [31]. Hence, they are the subject of many studies.

Recently, fungal pigments have been used for textile dyes, food colorants, antimicrobial and anticancer applications. They are also natural without having undesirable effects on the environment. Many scientific researchers have proved that pigments from soil fungi are a safer alternative to synthetic colorants, and there is good scope for industrial application [32,33].

\section{Fungal Pigments and Toxicity Evaluation}

Most fungi produce pigments along with mycotoxins. The presence of mycotoxins in pigments restricts the application of pigments as an additive in the food industry [16,34]. The European Union and the United States prohibit the consumption of Monascus pigments that are produced along with citrinin toxin, which poses a challenge over its safe use [35]. In short, natural pigments are a potential source of colorants that are eco-friendly, biodegradable, antimicrobial and have antioxidant properties. Apart from food additives, they are also used in cosmetics, pharmaceuticals and drug applications [36] (Table 1). 
Table 1. Important fungal pigments and their safety evaluation.

\begin{tabular}{|c|c|c|c|c|c|c|}
\hline Fungus & Pigment(s) & Color & Mycotoxin(s) & Safety Evaluation & Biological Activity & Reference(s) \\
\hline Aspergillus carbonarius & Melanins & Yellow & $\begin{array}{l}\text { Not described/not found } \\
\text { up to now }\end{array}$ & Subacute toxicity study & Antioxidant & [37] \\
\hline Blackeslea trispora & B-carotene & Red-orange & $\begin{array}{l}\text { Aflatoxin } \\
\text { Mycotoxin }\end{array}$ & $\begin{array}{l}\text { Genotoxicity and subacute } \\
\text { toxicity study }\end{array}$ & $\begin{array}{l}\text { Antioxidant, } \\
\text { anticancer, suppression } \\
\text { of cholesterol synthesis }\end{array}$ & {$[38,39]$} \\
\hline Fusarium graminearum & Rubrofusarin & Red & $\begin{array}{l}\text { Fumonisins, Zearalenone, } \\
\text { Fusaric Acid, Fusarins } \\
\text { and Beauvericins }\end{array}$ & Cytotoxic in colon cells & $\begin{array}{l}\text { Antimicrobial, } \\
\text { antiallergic, phytotoxicic }\end{array}$ & [40-42] \\
\hline Fusarium fujikuroi & Fusarubin & Orange & $\begin{array}{l}\text { Fumonisins, Zearalenone, } \\
\text { Fusaric Acid, Fusarins } \\
\text { and Beauvericins }\end{array}$ & $\begin{array}{l}\text { Cytotoxic against } \\
\text { leukemia cells }\end{array}$ & Anticancer, antimicrobial & {$[42,43]$} \\
\hline Fusarium oxysporum & Bikaverin & Red & $\begin{array}{l}\text { Fumonisins, Zearalenone, } \\
\text { Fusaric Acid, Fusarins } \\
\text { and Beauvericins }\end{array}$ & $\begin{array}{l}\text { Cytotoxic against tumour } \\
\text { cells, apoptosis suppressor }\end{array}$ & Antimicrobial, antitumour & {$[44]$} \\
\hline Monascus purpureus & $\begin{array}{l}\text { Monascorubramine } \\
\text { rubropunctamine }\end{array}$ & Red & Citrinin & Acute oral toxicity & Antihypertensive metabolite & [45] \\
\hline Monascus ruber & $\begin{array}{l}\text { Monascorubrin } \\
\text { and rubropunctatin }\end{array}$ & Orange-red & No coproduction of toxin & Oral toxicity & $\begin{array}{l}\text { Anti-inflammatory, anticancer } \\
\text { andantihyperlipidemic activities }\end{array}$ & [47] \\
\hline \multirow[t]{2}{*}{ Penicillium purpurogenum } & Azaphilone & Brick red pigment & No coproduction of toxin & $\begin{array}{l}\text { Brine shrimp } \\
\text { Artemia salina study }\end{array}$ & Pharmaceutical and food industry & {$[3,48,49]$} \\
\hline & $\begin{array}{l}\text { Purpurogenone } \\
\text { Mitorubrino } \\
\text { Mitorubrin }\end{array}$ & $\begin{array}{l}\text { Yellow-orange } \\
\text { Orange-red } \\
\text { Yellow }\end{array}$ & & & & \\
\hline Penicillium europium & Benzoquinone & Pinkish red & Nontoxic & Subacute toxicity study & Antimicrobial & {$[50]$} \\
\hline Penicillium resticulosum & $\begin{array}{l}\text { Not described/not found } \\
\text { up to now }\end{array}$ & Red & Nontoxic & Subacute toxicity study & Antimicrobial & {$[51]$} \\
\hline
\end{tabular}


Table 1. Cont

\begin{tabular}{|c|c|c|c|c|c|c|}
\hline Fungus & Pigment(s) & Color & Mycotoxin(s) & Safety Evaluation & Biological Activity & Reference(s) \\
\hline Penicillium aculeatum & Ankaflavin & Yellow & $\begin{array}{l}\text { Nontoxic, selective toxicity } \\
\text { in cancer cells }\end{array}$ & Cytotoxicity study & Antimicrobial & {$[52]$} \\
\hline Talaromycespurpureogenus & $\begin{array}{l}\text { Purpuride, monascorubrin, } \\
\text { purpurquinone-A, ankaflavin, }\end{array}$ & Yellow and red & Nontoxic & Subacute toxicity study & Antioxidant & [53] \\
\hline Thermomyces sp. & Napthoquinone & Yellow & Nontoxic & Subacute toxicity study & $\begin{array}{l}\text { Antioxidant, antimicrobial } \\
\text { and food industry }\end{array}$ & {$[54]$} \\
\hline Trichoderma viride & $\begin{array}{l}\text { Emodin } \\
\text { Viridol }\end{array}$ & $\begin{array}{l}\text { Brown } \\
\text { Yellow }\end{array}$ & Nonphytotoxic & Phytotoxicity assay & Antimicrobial & [28] \\
\hline Scytalidium cuboideum & Xylindein & Red & Nontoxic & Zebrafish toxicity study & UV resistant & [55] \\
\hline Rhodotorula glutinis & $\begin{array}{l}\beta \text {-carotene, torulene } \\
\text { and torularhodin }\end{array}$ & Red and orange & Nontoxic & $\begin{array}{l}\text { Standard subchronic } \\
\text { toxicity study }\end{array}$ & $\begin{array}{l}\text { Antioxidant, } \\
\text { Antimicrobial } \\
\text { Food and feed additive }\end{array}$ & {$[56]$} \\
\hline Rhodotorula gracilis & $\begin{array}{l}\beta \text {-carotene, torulene } \\
\text { and torularhodin }\end{array}$ & Red and orange & Nontoxic & $\begin{array}{l}\text { Standard subchronic } \\
\text { toxicity study }\end{array}$ & Antimicrobial & {$[57,58]$} \\
\hline Yarrowia lipolytica & $\beta$-carotene & Brown & Nontoxic & $\begin{array}{l}\text { Genotoxicity models and a } \\
\text { standard subchronic } \\
\text { toxicity study }\end{array}$ & Antimicrobial & [59] \\
\hline
\end{tabular}




\subsection{Aspergillus carbonarius}

Aspergillus carbonarius, an Ascomycota fungus of the family Aspergillaceae, is capable of producing a yellow-colored pigment in its biomass. It does not produce any antinutrients or mycotoxins [60]. It has been exploited for large-scale production of polygalacturonase and is capable of temperature tolerance by UV irradiation when grown in shake-flask cultures. During the growth phase, a yellow colored pigment is accumulated in its biomass and has the potential to be used as a food colorant [61].

Toxicity studies in both sexes of albino rats at acute and subacute doses of the pigment revealed that feeding of fungal biomass did not show any mortality in rats and there are no significant differences in food intake or organ and body weight. When comparing treated and untreated rats, hematological parameters, serum enzymes lactate dehydrogenase (LDH), alkaline phosphatase (ALP), alanine aminotransferase (ALT or ALAT) and cholesterol assay also remain normal [62].

\subsection{Blackslea trispora}

Blakesleatrispora is a Zygomycetes fungus of the order Mucorales, family Choanephoraceae. It is capable of undergoing both sexual and asexual reproduction through the production of zygospores and sporangiospores. The fungus does not produce any toxic compounds; hence, it is of industrial interest as a source of $\beta$-carotene for commercial exploitation [63,64]. $\beta$-carotene from B. trispora was the first authorized microbial food colorant in the European Union. It is efficient and can achieve the highest yield of all trans $\beta$-carotene at the expense of other structurally related carotenoids [33]. The process production was improved over a number of years, producing carotenoid contents of up to $20 \%$ dry weight $[65,66]$.

The safety assessment of $\beta$-carotene, derived from $B$. trispora, has revealed no genotoxicity or subacute toxicity for 4 weeks $[38,67]$. A subchronic toxicity study of 90 days was performed with oral administration of F344.Rats of both sexes showed no adverse effects on their biological systems [39]. $\beta$-carotene derived from the B. trispora at a $5.0 \%$ dietary level, equivalent to $3127 \mathrm{mg} / \mathrm{kg} /$ day and $3362 \mathrm{mg} / \mathrm{kg} /$ day for male and female rats, caused no adverse effects. The findings revealed that the daily intake of synthetic $\beta$-carotene from B. trispora by human beings is a negligible toxicological hazard [68].

\subsection{Fusarium sp.}

Fusarium are Ascomycota fungi that belong to the order Hypocreales, family Nectriaceae. They produce a wide range of fungal pigments that are structurally and functionally diverse. However, among the Fusarium sp., Fusarium graminearum (red naphthoquinone pigment, rubrofusarin) [40], Fusarium fujikuroi (orange carotenoids pigment, fusarubin) $[43,69]$ and Fusarium oxysporum (red naphthoquinone pigment, bikaverin) [44] are the major pigment-producing fungi. Secondary metabolites from these fungi contain numerous toxic compounds, viz., fumonisins, zearalenone, fusaric acid, fusarins and beauvericins [70].

Toxicity analysis revealed that the red dimeric naphthoquinone pigment from F. oxysporumcontaminated products affects human health. Recently, red naphthoquinone pigment has often been reported as a mycotoxin. However, naphthoquinone pigment was not genotoxic according to a DNA synthesis assay. Biotechnological approaches and intelligent screening of the toxic metabolite pathway of the pigment from Fusarium sp. will be helpful in producing the pigment for food coloring [41,42].

\subsection{Monascus sp.}

Monascus sp. are fungi placed under order Eurotiales, family Monascaceae. There are many species in this genus, among which $M$. purpureus (monascorubramine and rubropunctamine) [45], M. anka (ankaflavin and monascin) [46] and M. ruber (monascorubrinandrubropunctatin) [47] are of greatest significance to the food industry. Traditionally, Monascus pigments were produced on rice using solid-state microbial fermentation. Synonyms for this food product include, Hon-Chi, Hong Qu, Dan Qu, Anka, Ankak rice, 
Beni-Koji, red koji, red Chinese rice, red yeast rice and red mold rice (RMR). RMR was utilized as a food colorant in traditional Chinese medicine for more than 1000 years [71].

Chinese, as well as other East Asian people, have confirmed the safety of red yeast rice. The European Food Safety Authority (EFSA) and the United States excluded red yeast rice on the list of permissible food additives, due to complex secondary metabolites $[72,73]$. The toxigenic strain of Monascus purpureus is capable of producing nephrotoxic and hepatotoxic mycotoxin citrinin, which limits the wide application of the pigment [74].

For more than a thousand years, pigments produced by Monascus sp. were legally used as food colorants in South East Asia, even though they were demonstrated to have physiological effects. There are numerous toxicological data available on this Monascus red pigment.

A genetically modified industrial strain, M. purpureus SM001 isolated in China, is capable of producing pigment without citrinin, which is the best Monascus pigment producer.This results in the prolonged safety of Monascus-related products and their application [75].

\subsection{Penicillium sp.}

Penicillium are Ascomycota fungi belonging to the order Eurotiales, family Trichocomaceae. They are capable of producing many pigments. Penicillium are ubiquitous saprophytic soil fungi, present wherever organic material is available. Several species are capable of producing highly toxic mycotoxins. Some species of the genus Penicillium are capable of producing antibiotics, while some other species are used in cheese making; however, pigment production by these fungi is less well known [48,76]. Patents contain information about acute oral toxicity in mice. A 90-day subchronic toxicological study found acute dermal irritation, acute eye irritation, antitumor activity, micronucleus test in mice, AMES test (Salmonella typhimurium reverse mutation assay) and an estimation of antibiotic activity, including results of estimation of five mycotoxins [77].

Penicillium purpurogenum is capable of producing an azaphilone-like pigment. It secretes a brick red pigment during growth, which generally diffuses into commonly used media. However, violet pigment (PP-V) and orange pigment (PP-O) were also reported by altering culture conditions [78]. The production of pigment from Penicillium is more efficient and profitable than any other microorganism. It secretes enzymes and pigments out of the cell and the secreted pigment is water-soluble and relatively stable; thus, it is easily purified [79].

Toxicity studies of P. purpurogenum DPUA 1275 on brine shrimp, Artemia salina, showed antimicrobial effects and absence of toxicity to go along with pigment production. It also does not produce any known mycotoxins and is nonpathogenic to humans. It is a potential strain for the production of food pigments [80]. Although many species of Penicillium are found to produce pigments, only a few toxicological studies have been conducted.

Penicillium europium, isolated from forest soil, is capable of producing a pinkish pigment by using longifolene as a sole carbon source. A toxicity study on albino rats revealed that the pigment had no toxic effect on rats. Synthesized pigments from P. europium could be used in food, feed and pharmaceutical industries. Apart from the food industry, it could be used for various industrial applications, viz., dyes for textile and non-textile substrates such as paper, leather, paints and cosmetics. Moreover, as it is non cytotoxic, the pigment could be a potential replacement for hazardous synthetic dyes $[50,81]$.

Penicillium resticulosum is capable of producing red pigments. An evaluation of the subacute toxicity of oral exposure on the synthesized pigment on adult male and female mice for 28 days, using a pigment dose of up to $500 \mathrm{mg} \mathrm{kg}^{-1}$ body weight daily, had no effect on body weight, organ weight, or the activity of lactate dehydrogenase (LDH), alkaline phosphatase (ALP), alanine aminotransferase (ALT or ALAT) enzymes or blood urea nitrogen (BUN) levels. However, mice taking the pigment over $500 \mathrm{mg} \cdot \mathrm{kg}^{-1}$ body weight daily showed fatty degeneration and mild necrosis of liver cells, indicating that doses under $500 \mathrm{mg} \cdot \mathrm{kg}^{-1}$ body weight were safe for daily consumption [51,82]. 
Penicillium aculeatum produces a yellow (ankaflavin) pigment under submerged fermentation. Cytotoxicity studies of the pigment interacting with human colon carcinoma cell lines (HCT116) and human prostatic carcinoma cell lines (PC3) exhibited apoptosis and cell cycle inhibition at lower concentrations. An assay of human erythrocytes and human embryonic kidney (HEK-293) cell lines showed the least cytotoxicity atfor highest concentrations tested. Displaying selective cytotoxicity is an important property for an ideal anticancer drug [52].

\subsection{Talaromyces purpureogenus}

Talaromyces purpureogenus (basionym: Penicillium purpureogenum), is capable of producing yellow and red pigments under submerged fermentation. Pigments from T. purpureogenus CFRM02 are non toxic to Artemia franciscana (brine shrimp). In a single-dose acute toxicity study, (50, 300, 1000 and $2000 \mathrm{mg} / \mathrm{kg}$ body weight) conducted on female Wistar rats, there was no evidence of adverse effects on body weight and mortality after 14 days. Subacute studies (250-1000 mg/kg body weight) showed no significant changes in food intake, body weight gain and relative weight of vital organs after 28 days. Furthermore, a histopathological examination of the liver and kidney was normal. There were no significant changes in serum enzyme activities in the treated and control groups (acute and subacute). Safety efficacy of the pigment from T. purpureogenus CFRM02 is suggested for application in food and nutraceuticals [53]. This potential strain has resulted in in-depth studies of some strains of Talaromyces species, viz., Talaromyces aculeatus, T. funiculosum, T. pinophilus and T. purpurogenum. They are capable of producing Monascus-like polyketide azaphilone pigments, with or without coproducing citrinin or any other known mycotoxins [83].

\subsection{Thermomyces sp.}

Thermomyces are Ascomycota fungi ofthe order Eurotiales, family Trichocomaceae, and they are capable of producing a yellow pigment. They are thermophilic and hemicellulose degraders. One strain was isolated from soil in Kodaikanal, Dindugul District, Tamil Nadu, India. The yellow pigment can scavenge reactive oxygen species (ROS) induced by chemicals and UV rays and reduce the DNA damage by their antioxidant capabilities [84]. The bright pigmentation varies from yellow to red, depending on the growth, temperature, age and substrate [85].Food and beverages fortified by the yellow pigment recorded high antioxidant properties, antimicrobial properties and color stability [86].

Toxicological studies on the Thermomyces pigment using albino mice that orally ingested Thermomyces sp. pigment for 28 days showed no alterations in red blood cells, white blood cells, haemoglobin, organ weight orhistopathology of the liver or kidneys [54] (Figure 3). Apart from pigmentation, in vivo antioxidant activity was also observed [87,88]. Therefore, pigments from Thermomyces sp. could be safe for the food industry.

\subsection{Trichoderma viride}

Trichoderma viride is an Ascomycota fungus belonging to the order Hypocreales, family Hypocreaceae. It is capable of producing a brown colored pigment, identified as furfural (only one study and this should be confirmed) [89]. It is mostly used as a biological control agent against soil-borne plant pathogenic fungi. It is also capable of synthesizing emodin, a yellow pigment. T. polysporum is the only fungi capable of producing emodin in culture media. A phytotoxicity assay proved the nontoxic nature of $T$. viride on the germination of Phaseolus aureus Roxb. The pigment, i.e., furfural, produced by Trichoderma viride, has possible wide applications in various industries [89].

\subsection{Scytalidium cuboideum}

Scytalidium cuboideum, an Ascomycota fungus belonging to the order Helotiales, family Chaetomiaceae, is isolated from wood and is capable of coloring wood. It produces a red pigment, identified as xylindein. 
Toxicity studies of the red pigment in zebrafish revealed a relatively high LD50 value, making it unlikely to affect humans. Pure solidified pigments from S. cuboideum did not demonstrate toxicity. However, significant mortality was associated with impure fungal metabolites containing pigments. Hence, xylindein is considered as an environmentally safe pigmentation for future applications $[55,90]$.

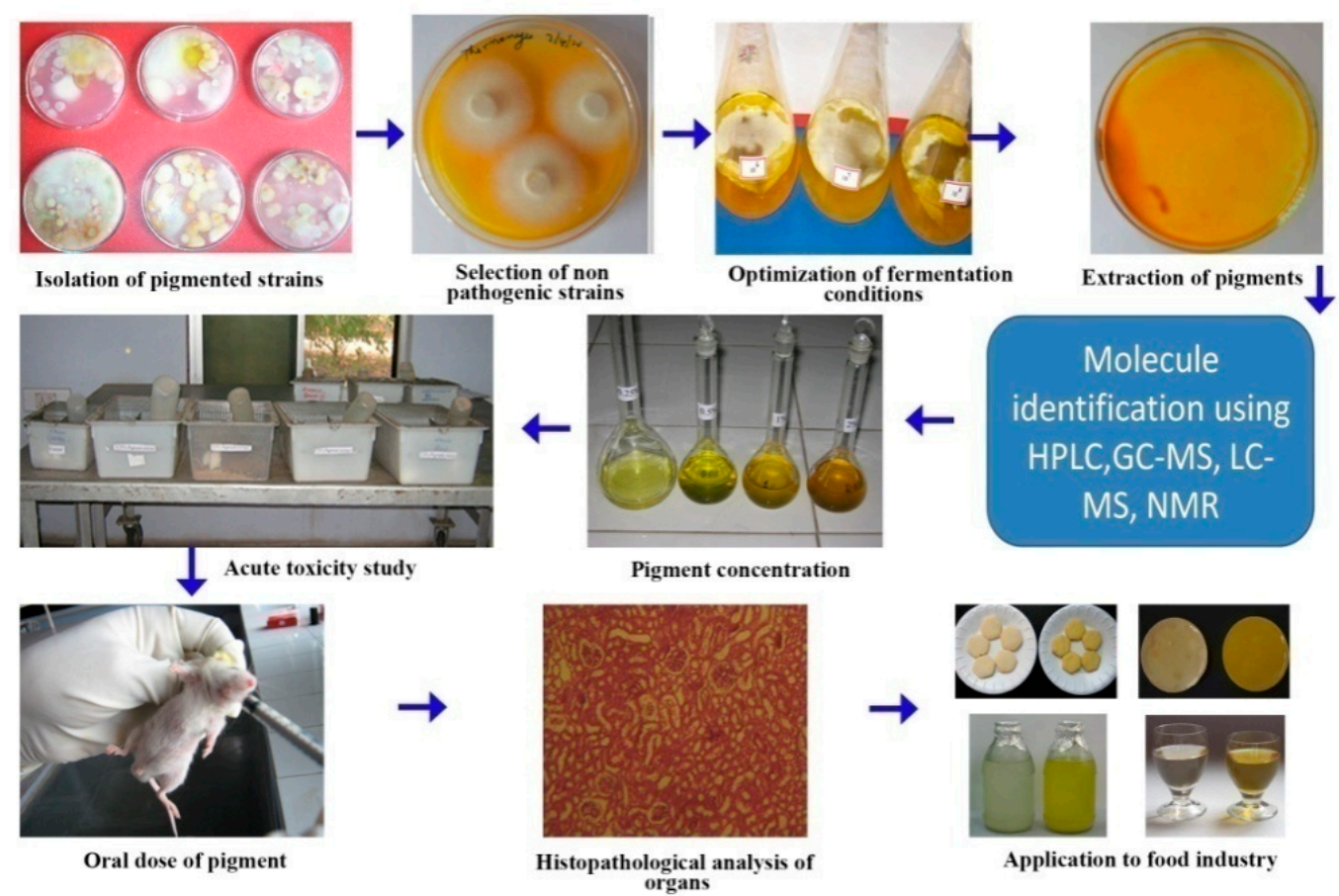

Figure 3. Toxicity evaluation of Thermomyces sp. pigment using an animal model.

\subsection{Neurospora crassa}

Neurospora crassa is a type of red bread mold of the phylum Ascomycota in the order Sordariales, family Sordariaceae. It is a genetically and biochemically well-studied eukaryotic microorganism [91,92]. It is capable of producing polyketide and carotenoid fungal pigments that are yellow to orange-red pigments widely used as food colorants. Research on Neurospora sp. has generally recognized it as safe after more than two centuries, with no record of mycotoxin production. For the production of ethanol, biomass and pigments, it can be grown rapidly on industrial residuals and lignocelluloses.

\subsection{Other Fungal Pigments}

The Cordycipitaceae family have promising pigment-producing genera such as Torrubiella, Cordyceps, Beauveria, Hyperdermium and Lecanicillium. Beauveria bassiana produces tenellin and Beauveria brongniartii produces bassianin. Beauveria bassiana produces pyridovericin, blood-red dibenzoquinone and pyridomacrolidin, along with mycotoxin. Torubiella produces torrubiellones and Lecanicillium aphanocladii produces a pigment, along with oosporein [93]. This molecule has a wide range of bioactivities from antifungal, antimicrobial and phytotoxic effects to growth inhibition in plants. Additionally, kidney damage and even death were noticed in poultry exposed to oosporein.

\section{Yeast}

Yeast synthesizes a variety of commercially important carotenoids, viz., carotene, torulene, torularhodin and astaxanthin. Genera Rhodotorula, Sporobolomyces and Phaffia are potential sources of pigments. Carotenoids from yeast are used in pharmaceutical, chemical, food and feed industries. They are also an important precursor for vitamin A synthesis. Apart from coloring, it also has antioxidant and possible tumor-inhibiting properties [94,95]. 


\subsection{Rhodotorula sp.}

Rhodotorula a pigment-producing yeasts from division Basidiomycota are capable of synthesizing carotenoid pigments. Other species such as R. gracilis, R. rubra and R. graminis are also capable of producing pigments. The main compounds produced by Rhodotorula glutinis (red yeasts) are torulene and torularhodin, with a minute quantity of $\beta$-carotene $[96,97]$.

A toxicological evaluation of $R$. gracilis CFR-1, using acute doses in freeze-dried form at $0.5-6.0 \mathrm{~g} / \mathrm{kg}$ of body weight $(w / w)$, did not show any toxic symptoms or mortality in adult rats. Dietary intake at low concentrations of $0.1-2.0 \%$ level $(w / w)$ for 14 weeks did not induce any significant change in food intake and body weight gain in experimental rats compared to control animals [56,57].

Toxicity studies of $\beta$-carotene, torulene and torularhodin produced by $R$. glutinis conducted on rats demonstrated that they can be used as safe food additives. Dry powdered R. glutinis NCIM 3353 yeast biomass was added to the fodder of rats. The rats had protective effects against precancerous lesions of the liver induced by N-nitrosodimethylamine [98].

\subsection{Yarrowia lipolytica}

Yarrowia lipolytica is an Ascomycetous yeast and the only described species of the genus Yarrowia. It is widespread in nature, has many industrial uses and is important in the food industry and medical field. It is used as an alternative source of $\beta$-carotene. The major constituents of the carotenoids include all-trans- $\beta$-carotene with small amounts of 9-cis $\beta$-carotene, 15 -cis $\beta$-carotene, 13-cis $\beta$-carotene and others [99].

Toxicity studies of $\beta$-carotene from Y. lipolytica in genotoxicity models and a standard subchronic rat study revealed no significant difference, compared with commercial products. An extracellular nontoxic pyomelanin pigment from Y. lipolytica was found to have antioxidant and noncytotoxic properties for two mammalian cell lines, viz., mouse fibroblast (NIH3T3) and human keratinocytes (HaCaT). Purified pyomelanin has a significant sun protection factor (SPF) value, highlighting its potential as a UVfilter in cosmetic preparations. Biomass of this yeast was defined as a safe novel food by the European Food Safety Authority [100].

\section{Conclusions}

In recent decades, natural pigments have been extensively used as colorants in food, pharmaceutical, cosmetic and textile industries. Several fungal strains are known for pigment production, while many fungi have not been systematically explored for their pigment-producing capability. Therefore, there is a need to explore novel and safe pigments using appropriate tools and techniques. Many pigments, including those with antibioticlike properties, need to be studied for selective toxicity so that they can be produced commercially for human use. Fungal pigments open many new avenues in the production of textiles for medical use. This provides an extensive area of exploration to identify natural, eco-friendly pigments for diverse applications to satisfy public demand. In addition, biotechnological approaches help to produce pigments on a large scale with low cost, high yield and easy extraction without mycotoxins. The manufacture of fungal pigments has taken a big step to promote eco-friendly pigments. A literature search reveals the application of fungal pigments in the food and health care industries. These fungal pigments need to pass toxicity tests, quality tests and regulatory approval before their final entry into the market as food colorants or as drugs. Moreover, toxicology testing for most of the fungal pigments was not available. Another major impediment is that the funding required to carry out the necessary safety studies on such food additives is not available. For the above pigments to be feasible, testing is imperative. Fungal pigments could be a boon to the food industry.

Author Contributions: Writing-original draft, conceptualization (R.P.); writing-review and editing, supervision, resources (S.P.); supervision, conceptualization, writing-review and editing, 
validation (L.D.); visualization, supervision, conceptualization, resources (J.K.). All authors have read and agreed to the published version of the manuscript.

Funding: This research received no external funding.

Institutional Review Board Statement: Not applicable.

Informed Consent Statement: Not applicable.

Data Availability Statement: Not applicable.

Conflicts of Interest: The authors declare no conflict of interest. The funders had no role in the design of the study; in the collection, analyses, or interpretation of data; in the writing of the manuscript, or in the decision to publish the results.

\section{References}

1. Kalra, R.; Conlan, X.A.; Goel, M. Fungi as a Potential Source of Pigments: Harnessing Filamentous Fungi. Front. Chem. 2020, 8, 369. [CrossRef] [PubMed]

2. Yusuf, M.; Shabbir, M.; Mohammad, F. Natural Colorants: Historical, Processing and Sustainable Prospects. Nat. Prod. Bioprospecting 2017, 7, 123-145. [CrossRef]

3. Martins, N.; Roriz, C.L.; Morales, P.; Barros, L.; Ferreira, I.C.F.R. Food colorants: Challenges, opportunities and current desires of agro-industries to ensure consumer expectations and regulatory practices. Trends Food Sci. Technol. 2016, 52, 1-15. [CrossRef]

4. Ntrallou, K.; Gika, H.; Tsochatzis, E. Analytical and Sample Preparation Techniques for the Determination of Food Colorants in Food Matrices. Foods 2020, 9, 58. [CrossRef]

5. Sigurdson, G.T.; Tang, P.; Giusti, M.M. Natural Colorants: Food Colorants from Natural Sources. Annu. Rev. Food Sci. Technol. 2017, 8, 261-280. [CrossRef]

6. Rodriguez-Amaya, D.B. Natural food pigments and colorants. Curr. Opin. Food Sci. 2016, 7, 20-26. [CrossRef]

7. Gmoser, R.; Ferreira, J.A.; Lennartsson, P.R.; Taherzadeh, M.J. Filamentous ascomycetes fungi as a source of natural pigments. Fungal Biol. Biotechnol. 2017, 4, 4. [CrossRef]

8. Narsing Rao, M.P.; Xiao, M.; Li, W.-J. Fungal and Bacterial Pigments: Secondary Metabolites with Wide Applications. Front. Microbiol. 2017, 8, 1113. [CrossRef] [PubMed]

9. Rao, P.; Bhat, R.V. A comparative study on the synthetic food colours usage in foods procured from urban and rural areas of Hyderabad. Nutr. Food Sci. 2003, 33, 230-234. [CrossRef]

10. Mittal, J. Permissible Synthetic Food Dyes in India. Resonance 2020, 25, 567-577. [CrossRef]

11. Oplatowska-Stachowiak, M.; Elliott, C.T. Food colors: Existing and emerging food safety concerns. Crit. Rev. Food Sci. Nutr. 2017, 57, 524-548. [CrossRef] [PubMed]

12. Feng, Y.; Shao, Y.; Chen, F. Monascus pigments. Appl. Microbiol. Biotechnol. 2012, 96, 1421-1440. [CrossRef] [PubMed]

13. WHO. Toxicological Evaluation of Certain Food Additives and Contaminants; WHO Food Additives Series; World Health Organization: Geneva, Switzerland, 1991; Volume 28.

14. Rao, P.; Bhat, R.V.; Sudershan, R.V.; Prasanna Krishna, T. Consumption of synthetic food colours during festivals in Hyderabad, India. Br. Food J. 2005, 107, 276-284. [CrossRef]

15. Rowe, K.S.; Rowe, K.J. Synthetic food coloring and behavior: A dose response effect in a double-blind, placebo-controlled, repeated-measures study. J. Pediatr. 1994, 125, 691-698. [CrossRef]

16. Dufossé, L.; Fouillaud, M.; Caro, Y.; Mapari, S.A.; Sutthiwong, N. Filamentous fungi are large-scale producers of pigments and colorants for the food industry. Curr. Opin. Biotechnol. 2014, 26, 56-61. [CrossRef]

17. Gupta, N.; Poddar, K.; Sarkar, D.; Kumari, N.; Padhan, B.; Sarkar, A. Fruit waste management by pigment production and utilization of residual as bioadsorbent. J. Environ. Manag. 2019, 244, 138-143. [CrossRef]

18. Aruldass, C.A.; Dufossé, L.; Ahmad, W.A. Current perspective of yellowish-orange pigments from microorganisms-A review. J. Clean. Prod. 2018, 180, 168-182. [CrossRef]

19. Panesar, R.; Kaur, S.; Panesar, P. Production of microbial pigments utilizing agro-industrial waste: A review. Curr. Opin. Food Sci. 2015, 1, 70-76. [CrossRef]

20. Tirumale, S.; Wani, N.A. Biopigments: Fungal Pigments; Springer: Singapore, 2018.

21. Nigam, P.S.; Luke, J.S. Food additives: Production of microbial pigments and their antioxidant properties. Curr. Opin. Food Sci. 2016, 7, 93-100. [CrossRef]

22. Venil, C.K.; Zakaria, Z.A.; Ahmad, W.A. Bacterial pigments and their applications. Process. Biochem. 2013, 48, 1065-1079. [CrossRef]

23. Joshi, V.A.; Bala, A.; Bhushan, S. Microbial Pigments. Indian J. Biotechnol. 2003, 2, 362-369.

24. Chattopadhyay, P.; Chatterjee, S.; Sen, S.K. Biotechnological potential of nature food grade biocolourants. Afr. J. Biotechnol. 2008, 7, 2972-2985.

25. Lin, L.; Xu, J. Fungal Pigments and Their Roles Associated with Human Health. J. Fungi 2020, 6, 280. [CrossRef] 
26. Tuli, H.S.; Chaudhary, P.; Beniwal, V.; Sharma, A.K. Microbial pigments as natural color sources: Current trends and future perspectives. J. Food Sci. Technol. 2015, 52, 4669-4678. [CrossRef] [PubMed]

27. Velmurugan, P.; Kim, M.-J.; Park, J.-S.; Karthikeyan, K.; Lakshmanaperumalsamy, P.; Lee, K.-J.; Park, Y.-J.; Oh, B.-T. Dyeing of cotton yarn with five water soluble fungal pigments obtained from five fungi. Fibers Polym. 2010, 11, 598-605. [CrossRef]

28. Nirlane da Costa Souza, P.; Luiza Bim Grigoletto, T.; Alberto Beraldo de Moraes, L.; Abreu, L.M.; Henrique Souza Guimarães, L.; Santos, C.; Ribeiro Galvão, L.; Gomes Cardoso, P. Production and chemical characterization of pigments in filamentous fungi. Microbiology 2016, 162, 12-22. [CrossRef]

29. Heo, Y.M.; Kim, K.; Kwon, S.; Na, J.; Lee, H.; Jang, S.; Kim, C.-H.; Jung, J.; Kim, J.-J. Investigation of Filamentous Fungi Producing Safe, Functional Water-Soluble Pigments. Mycobiology 2018, 46, 269-277. [CrossRef]

30. Mostafa, M.; Abbady, M. Secondary Metabolites and Bioactivity of the Monascus Pigments-Review Article. Glob. J. Biotechnol. Biochem. 2014, 9, 1-13.

31. Saravanan, A.; Jayasree, R.; Kumar, P.S.; Varjani, S.; Hemavathy, R.; Jeevanantham, S.; Yaashikaa, P.R. Production of pigment using Aspergillus tamarii: New potentials for synthesizing natural metabolites. Environ. Technol. Innov. 2020, 19, 100967. [CrossRef]

32. Kongsak Boonyapranai, R.T. Sorasak Lhieochaiphant and Suree Phutrakul. Optimization of Submerged Culture for the Production of Naphthoquinones Pigment by Fusarium verticillioides. Chiang Mai J. Sci. 2008, 35, 457-466.

33. Dufossé, L. Microbial Production of Food Grade Pigments. Food Technol. Biotechnol. 2006, 44, 313-321.

34. Lagashetti, A.C.; Dufossé, L.; Singh, S.K.; Singh, P.N. Fungal Pigments and Their Prospects in Different Industries. Microorganisms 2019, 7, 604. [CrossRef]

35. Carvalho, J.C.; Oishi, B.O.; Pandey, A.; Soccol, C. Biopigments from Monascus: Strains selection, citrinin production and color stability. Braz. Arch. Biol. Technol. 2005, 48, 885-894. [CrossRef]

36. Dufossé, L. 16-Current and Potential Natural Pigments From Microorganisms (Bacteria, Yeasts, Fungi, Microalgae). In Handbook on Natural Pigments in Food and Beverages; Carle, R., Schweiggert, R.M., Eds.; Woodhead Publishing: Sawston, UK, 2016; pp. 337-354. [CrossRef]

37. Bezirhan Arikan, E.; Canli, O.; Caro, Y.; Dufossé, L.; Dizge, N. Production of Bio-Based Pigments from Food Processing Industry By-Products (Apple, Pomegranate, Black Carrot, Red Beet Pulps) Using Aspergillus carbonarius. J. Fungi 2020, 6, 240. [CrossRef]

38. The Joint FAO/WHO Expert Committee on Food Additives. Evaluation of Certain Food Additives and Contaminants. FAO/WHO Expert Committee on Food Additive; World Health Organization: Geneva, Switzerland, 1996; pp. 1-100.

39. Woutersen, R.A.; Wolterbeek, A.P.; Appel, M.J.; van den Berg, H.; Goldbohm, R.A.; Feron, V.J. Safety evaluation of synthetic beta-carotene. Crit. Rev. Toxicol. 1999, 29, 515-542. [CrossRef]

40. Cambaza, E. Comprehensive Description of Fusarium graminearum Pigments and Related Compounds. Foods 2018, 7, 165. [CrossRef] [PubMed]

41. Díaz-Sánchez, V.; Avalos, J.; Limón, M.C. Identification and regulation of fusA, the polyketide synthase gene responsible for fusarin production in Fusarium fujikuroi. Appl. Environ. Microbiol. 2012, 78, 7258-7266. [CrossRef] [PubMed]

42. Soumya, K.; Narasimha Murthy, K.; Sreelatha, G.L.; Tirumale, S. Characterization of a red pigment from Fusarium chlamydosporum exhibiting selective cytotoxicity against human breast cancer MCF-7 cell lines. J. Appl. Microbiol. 2018, 125, 148-158. [CrossRef] [PubMed]

43. Menezes, B.S.; Solidade, L.S.; Conceição, A.A.; Santos Junior, M.N.; Leal, P.L.; de Brito, E.S.; Canuto, K.M.; Mendonça, S.; de Siqueira, F.G.; Marques, L.M. Pigment production by Fusarium solani BRM054066 and determination of antioxidant and anti-inflammatory properties. AMB Express 2020, 10, 117. [CrossRef] [PubMed]

44. Santos, M.C.d.; Mendonça, M.d.L.; Bicas, J.L. Modeling bikaverin production by Fusarium oxysporum CCT7620 in shake flask cultures. Bioresour. Bioprocess. 2020, 7, 13. [CrossRef]

45. Mohankumari, H.P.; Naidu, K.A.; Narasimhamurthy, K.; Vijayalakshmi, G. Bioactive Pigments of Monascus purpureus Attributed to Antioxidant, HMG-CoA Reductase Inhibition and Anti-atherogenic Functions. Front. Sustain. Food Syst. 2021, 5, 590427. [CrossRef]

46. Shi, K.; Tang, R.; Huang, T.; Wang, L.; Wu, Z. Pigment fingerprint profile during extractive fermentation with Monascus anka GIM 3.592. BMC Biotechnol. 2017, 17, 46. [CrossRef] [PubMed]

47. Darwesh, O.M.; Matter, I.A.; Almoallim, H.S.; Alharbi, S.A.; Oh, Y.-K. Isolation and Optimization of Monascus ruber OMNRC45 for Red Pigment Production and Evaluation of the Pigment as a Food Colorant. Appl. Sci. 2020, 10, 8867. [CrossRef]

48. Mapari, S.A.S.; Meyer, A.S.; Thrane, U.; Frisvad, J.C. Identification of potentially safe promising fungal cell factories for the production of polyketide natural food colorants using chemotaxonomic rationale. Microb. Cell Factories 2009, 8, 24. [CrossRef] [PubMed]

49. Mapari, S.A.S.; Meyer, A.S.; Thrane, U.; Frisvad, J. Production of Monascus-like Pigments. European Patent EP2262862B1, 28 March 2012.

50. Khan, A.A.; Iqubal, S.S.; Shaikh, I.A.; Niyongabo Niyonzima, F.; More, V.S.; Muddapur, U.M.; Bennur, R.S.; More, S.S. Biotransformation of longifolene by Penicillium europium. Biocatal. Biotransform. 2021, 39, 41-47. [CrossRef]

51. Sopandi, T.; Wardah, W. Sub-Acute Toxicity of Pigment Derived from Penicillium resticulosum in Mice. Microbiol. Indones. 2012, 6, 6. [CrossRef]

52. Krishnamurthy, S.; Narasimha Murthy, K.; Thirumale, S. Characterization of ankaflavin from Penicillium aculeatum and its cytotoxic properties. Nat. Prod. Res. 2020, 34, 1630-1635. [CrossRef] 
53. Gopal Pandit, S.; Honganoor Puttananjaiah, M.; Serva Peddha, M.; Appasaheb Dhale, M. Corrigendum to 'Safety efficacy and chemical profiling of water-soluble Talaromyces purpureogenus CFRM02 pigment' [Food Chem. 310 (2020) 125869]. Food Chem. 2020, 317, 126403. [CrossRef]

54. Poorniammal, R.; Gunasekaran, S.; Sriharasivakumar, H. Toxicity evaluation of funfal food colourant from Thermomyces sp in albino mice. J. Sci. Ind. Res. 2011, 70, 773-777.

55. Almurshidi, B.H.; Van Court, R.C.; Vega Gutierrez, S.M.; Harper, S.; Harper, B.; Robinson, S.C. Preliminary Examination of the Toxicity of Spalting Fungal Pigments: A Comparison between Extraction Methods. J. Fungi 2021, 7, 155. [CrossRef] [PubMed]

56. Latha, B.V.; Jeevaratanm, K. Thirteen-week oral toxicity study of carotenoid pigment from Rhodotorula glutinis DFR-PDY in rats. Indian J. Exp. Biol. 2012, 50, 645-651.

57. Naidu, K.A.; Venkateswaran, G.; Vijayalakshmi, G.; Manjula, K.; Viswanatha, S.; Murthy, K.N.; Srinivas, L.; Joseph, R. Toxicological assessment of the yeast Rhodotorula gracilis in experimental animals. Z. Für Lebensm. Und Forsch. A 1999, 208, 444-448. [CrossRef]

58. Kot, A.M.; Błażejak, S.; Gientka, I.; Kieliszek, M.; Bryś, J. Torulene and torularhodin: "new" fungal carotenoids for industry? Microb. Cell Fact. 2018, 17, 49. [CrossRef] [PubMed]

59. Groenewald, M.; Boekhout, T.; Neuvéglise, C.; Gaillardin, C.; van Dijck, P.W.; Wyss, M. Yarrowia lipolytica: Safety assessment of an oleaginous yeast with a great industrial potential. Crit. Rev. Microbiol. 2014, 40, 187-206. [CrossRef] [PubMed]

60. Venkatesh, K.S. Strain and Process Improvement for Polygalacturonase Production by Aspergillus carbonarius. Ph.D. Thesis, University of Mysore, Mysore, India, 2004.

61. Narendrababu, B.N.; Shishupala, S. Spectrophotometric detection of pigments from Aspergillus and Penicillium isolates. J. Appl. Biol. Biotechnol. 2017, 5, 53-58. [CrossRef]

62. Sanjay, K.R.; Kumaresan, N.; Akhilender Naidu, K.; Viswanatha, S.; Narasimhamurthy, K.; Umesh Kumar, S.; Vijayalakshmi, G. Safety evaluation of pigment containing Aspergillus carbonarius biomass in albino rats. Food Chem. Toxicol. 2007, 45, 431-439. [CrossRef]

63. Mantzouridou, F.; Tsimidou, M.Z. On the monitoring of carotenogenesis by Blakeslea trispora using HPLC. Food Chem. 2007, 104, 439-444. [CrossRef]

64. Sen, T.; Barrow, C.J.; Deshmukh, S.K. Microbial Pigments in the Food Industry-Challenges and the Way Forward. Front. Nutr. 2019, 6, 7. [CrossRef]

65. Papaioannou, E.H.; Liakopoulou-Kyriakides, M. Substrate contribution on carotenoids production in Blakeslea trispora cultivations. Food Bioprod. Process. 2010, 88, 305-311. [CrossRef]

66. Papadaki, E.; Mantzouridou, F. Natural ${ }^{2}$-Carotene Production by Blakeslea trispora Cultivated in Spanish-Style Green Olive Processing Wastewaters. Foods 2021, 10, 327. [CrossRef]

67. Finkelstein, M.; Huang, C.C.; Byng, G.S.; Tsau, B.R.; Leach, J. Blakeslea Trispora Mated Culture Capable of Increased Beta-carotene Production. U.S. Patent US5422247A, 6 June 1995.

68. Nabae, K.; Ichihara, T.; Hagiwara, A.; Hirota, T.; Toda, Y.; Tamano, S.; Nishino, M.; Ogasawara, T.; Sasaki, Y.; Nakamura, M.; et al. A 90-day oral toxicity study of beta-carotene derived from Blakeslea trispora, a natural food colorant, in F344 rats. Food Chem. Toxicol. 2005, 43, 1127-1133. [CrossRef] [PubMed]

69. Tudzynski, B. Gibberellin biosynthesis in fungi: Genes, enzymes, evolution, and impact on biotechnology. Appl. Microbiol. Biotechnol. 2005, 66, 597-611. [CrossRef]

70. Avalos, J.; Prado-Cabrero, A.; Estrada, A.F. Neurosporaxanthin production by Neurospora and Fusarium. Methods Mol. Biol. 2012, 898, 263-274. [CrossRef]

71. Ma, J.; Li, Y.; Ye, Q.; Li, J.; Hua, Y.; Ju, D.; Zhang, D.; Cooper, R.; Chang, M. Constituents of red yeast rice, a traditional Chinese food and medicine. J. Agric. Food Chem. 2000, 48, 5220-5225. [CrossRef] [PubMed]

72. Chen, W.; He, Y.; Zhou, Y.; Shao, Y.; Feng, Y.; Li, M.; Chen, F. Edible Filamentous Fungi from the Species Monascus: Early Traditional Fermentations, Modern Molecular Biology, and Future Genomics. Compr. Rev. Food Sci. Food Saf. 2015, 14, 555-567. [CrossRef]

73. Kallscheuer, N. Engineered Microorganisms for the Production of Food Additives Approved by the European Union-A Systematic Analysis. Front. Microbiol. 2018, 9, 1746. [CrossRef]

74. Liu, J.; Zhou, Y.; Yi, T.; Zhao, M.; Xie, N.; Lei, M.; Liu, Q.; Shao, Y.; Chen, F. Identification and role analysis of an intermediate produced by a polygenic mutant of Monascus pigments cluster in Monascus ruber M7. Appl. Microbiol. Biotechnol. 2016, 100, 7037-7049. [CrossRef]

75. Blanc, P.J.; Loret, M.O.; Goma, G. Production of citrinin by various species ofMonascus. Biotechnol. Lett. 1995, 17, 291-294. [CrossRef]

76. Gunasekaran Sanjeevi, P.R. Optimization of fermentation conditions for red pigment production from Penicillium sp. under submerged cultivation. Afr. J. Biotechnol. 2008, 7, 1894-1898. [CrossRef]

77. Sardaryan, E.; Zihlova, H.; Strnad, R.; Cermakova, Z. Arpink red-meet a new natural red food colourant of microbial origin. In Pigments in Food, More Than Colours; Elsevier: Amsterdam, TheNetherlands, 2004; pp. 207-208.

78. Kojima, R.; Arai, T.; Matsufuji, H.; Kasumi, T.; Watanabe, T.; Ogihara, J. The relationship between the violet pigment PP-V production and intracellular ammonium level in Penicillium purpurogenum. AMB Express 2016, 6, 43. [CrossRef]

79. Corrêia Gomes, D.; Takahashi, J.A. Sequential fungal fermentation-biotransformation process to produce a red pigment from sclerotiorin. Food Chem. 2016, 210, 355-361. [CrossRef] [PubMed] 
80. Visagie, C.M.; Houbraken, J.; Frisvad, J.C.; Hong, S.B.; Klaassen, C.H.W.; Perrone, G.; Seifert, K.A.; Varga, J.; Yaguchi, T.; Samson, R.A. Identification and nomenclature of the genus Penicillium. Stud. Mycol. 2014, 78, 343-371. [CrossRef]

81. Khan, A.A.; Alshabi, A.M.; Alqahtani, Y.S.; Alqahtani, A.M.; Bennur, R.S.; Shaikh, I.A.; Muddapur, U.M.; Iqubal, S.M.S.; Mohammed, T.; Dawoud, A.; et al. Extraction and identification of fungal pigment from Penicillium europium using different spectral studies. J. King Saud Univ. Sci. 2021, 33, 101437. [CrossRef]

82. Sethi, B.K.P.; Parida, P.; Sahoo, S.L.; Dikshit, B.; Pradhan, C.; Sena, S.; Behera, B.C. Extracellular production and characterization of red pigment from Penicillium purpurogenum BKS9. Alger. J. Nat. Prod. 2016, 4, 379-392.

83. Pandit, S.G.; Puttananjaih, M.H.; Harohally, N.V.; Dhale, M.A. Functional attributes of a new molecule-2-hydroxymethyl-benzoic acid 2'-hydroxy-tetradecyl ester isolated from Talaromyces purpureogenus CFRM02. Food Chem. 2018, 255, 89-96. [CrossRef]

84. Poorniammal, R.; Gunasekaran, S.; Gnanasambandam, A.V.; Murugesan, R. Process of Extracting Yellow Pigment from Thermomyces sp. Indian Patent 304979, 15 December 2018.

85. Somasundaram, T.; Rao, S.S.R.; Maheswari, R. Pigments in Thermophilic fungi. Curr. Sci. 1986, 55, 957-960.

86. Poorniammal, R.; Balachandar, D.; Gunasekaran, S. Evaluation of antioxidant property of some fungal pigments by DNA protection assay. Ann. Phytomedicine 2018, 7, 106-111. [CrossRef]

87. Poorniammal, R.; Gunasekaran, S.; Murugesan, R. In Vivo Antioxidant Activities of Thermomyces sp Pigment in Albino Mice. Int. J. Agric. Environ. Biotechnol. 2014, 7, 355-360. [CrossRef]

88. Poorniammal, R.; Prabhu, S.; Sakthi, A.R. Evaluation of In Vitro antioxidant activity of fungal pigments. Pharma Innov. 2019, 8, 326-330.

89. Chitale, A.; Jadhav, D.V.; Waghmare, S.R.; Sahoo, A.K.; Ranveer, R.C. Production and characterization of brown coloured pigment from Trichoderma viride. Electron. J. Environ. Agric. Food Chem. 2012, 11, 529-537.

90. Vega Gutierrez, S.M.; Stone, D.W.; He, R.; Vega Gutierrez, P.T.; Walsh, Z.M.; Robinson, S.C. Potential Use of the Pigments from Scytalidium cuboideum and Chlorociboria aeruginosa to Prevent 'Greying' Decking and Other Outdoor Wood Products. Coatings 2021, 11, 511. [CrossRef]

91. Perkins, D.D.; Davis, R.H. Evidence for safety of Neurospora species for academic and commercial uses. Appl. Environ. Microbiol. 2000, 66, 5107-5109. [CrossRef] [PubMed]

92. Priatni, S. Review: Potential production of carotenoids from Neurospora. Nusant. Biosci. 2016, 6, 63-68.

93. Gaffoor, I.; Brown, D.W.; Plattner, R.; Proctor, R.H.; Qi, W.; Trail, F. Functional analysis of the polyketide synthase genes in the filamentous fungus Gibberella zeae (anamorph Fusarium graminearum). Eukaryot. Cell 2005, 4, 1926-1933. [CrossRef] [PubMed]

94. Poorniammal, R.; Sarathambal, C.; Sakthi, A.R.; Arun, S. Yeast carotenoids importance in food and feed industries and its health benefits. Agric. Rev. 2013, 34, 307-312. [CrossRef]

95. Bogacz-Radomska, L.; Harasym, J. $\beta$-Carotene-properties and production methods. Food Qual. Saf. 2018, 2, 69-74. [CrossRef]

96. Bhosale, P.B.; Gadre, R.V. Production of beta-carotene by a mutant of Rhodotorula glutinis. Appl. Microbiol. Biotechnol. 2001, 55, 423-427. [CrossRef] [PubMed]

97. Zhao, Y.; Guo, L.; Xia, Y.; Zhuang, X.; Chu, W. Isolation, Identification of Carotenoid-Producing Rhodotorula sp. from Marine Environment and Optimization for Carotenoid Production. Mar. Drugs 2019, 17, 161. [CrossRef] [PubMed]

98. Bhosale, P.; Motiwale, L.; Ingle, A.D.; Gadre, R.V.; Rao, K.V.K. Protective effect of Rhodotorulaglutinis NCIM 3353 on the development of hepatic preneoplastic lesions. Curr. Sci. 2002, 83, 303-308.

99. Ben Tahar, I.; Kus-Liśkiewicz, M.; Lara, Y.; Javaux, E.; Fickers, P. Characterization of a nontoxic pyomelanin pigment produced by the yeast Yarrowia lipolytica. Biotechnol. Prog. 2020, 36, e2912. [CrossRef]

100. Grenfell-Lee, D.; Zeller, S.; Cardoso, R.; Pucaj, K. The safety of $\beta$-carotene from Yarrowia lipolytica. Food Chem. Toxicol. 2014, 65, 1-11. [CrossRef] [PubMed] 